\title{
Biochemical Changes in the Tissues of Zebrafish (Danio rerio) Exposed to Organophosphorous Pesticides and Heavy Metal Cadmium
}

\author{
Lixiao Wang, Abeer Ghazie Azize Al-sawafi, and Yunjun Yan
}

\begin{abstract}
The acute toxicity of melathion (MAL), atrzine (ATR) and Cadmium (Cd) in zebrafish (Danio rerio) were investigated by acute toxicity $\left(\mathrm{LC}_{50}\right)$, and the results showed that the $96 \mathrm{~h} \quad \mathrm{LC}_{50}$ followed the order: MAL>Cd>ATR. Furthermore, the accumulation of ecotoxicity in zebrafish body and correlated biochemical responses in brain and muscles were explored and it was found that MAL, ATR and Cd could be rapidly accumulated in fish body shortly after exposure. The activities of superoxide dismutase and catalase in fish body increased after 96h exposure. The acute toxicity caused protein reduction in brain and muscles, and elevation of total lipid dry weight in fish body. Besides, some dose-dependent inhibition of AChE activity was found in brain and muscles of zebrafish exposed to higher concentrations of acute toxins. These can be employed in biomonitoring programs because they showed good correlation with toxins and were sensitive to different concentration patterns.
\end{abstract}

Index Terms-Acute toxicity, Danio rerio, heavy metal, organophosphorus

\section{INTRODUCTION}

With the uncontrolled globle development of industry from last century, both humans and other lifes are suffering directly or indirectly from various environmental problems, among which, water pollution is continuously posing serious threatens to us. Water sources can be directly polluted by domestic drainage, industrial effluents, medical waste and agricultural chemicals and then bioaccumulated harmful substance in aquatic organisms potentially pose a threaten to wildlife and humans [1].

Freshwater contamination with heavy metals has become a major concern over the past decades, not only because of their threat to public and water supply but also due to their damage to aquatic life, especially fish. Thus, heavy metal is considered to be one of the most important contamination sources strongly affecting fish population, growth and reproduction [2]. Instead of atmospheric sources, heavy metals often enter the environment mainly through human activities circulate in food webs and accumulate in living organisms [3]. Non-essential heavy metals are harmful and sometimes even lethal toxins that may lead to fertility decline, cellular damage, cell death and dysfunction of a variety of organs when accumulated in tissues [4]. Nevertheless, the ecological toxicity of heavy metals on the environment is still

Manuscript received June 23, 2017; revised August 31, 2017.

The authors are with Huazhong University of Science and Technology, China (e-mail: yanyunjun@hust.edu.cn). in the dark and unknown up to present. Therefore, more information is urgently required to unravel their acting mechanism and better understand the importance of these pollutants.

Pesticides play an important role in maintaining agricultural production through the protection of all types of crops from pest attack and vector-borne diseases, but some pesticides have adverse effects on fish and other non-target animals. Organophosphate (OP) compounds are extensively used in the fields of agriculture as well as public health, making up $50 \%$ of the insecticides use world wide, because such compounds can degrade promptly due to their non-persistent nature [5]. Wacksman et al. pointed out that OP could inhibite the activity of acetylcholinesterase (AChE), and consequently, acetylcholine accumulated in the cholinergic receptors of the central and peripheral nervous systems [6]. Despite the fact that AChE could be used to indicate exposure to OP pesticides in non-target taxa [7], yet there is increasing evidence showing that other categories of chemicals can also affect these enzymatic activities in fish, such as heavy metals and complex mixtures of pollutants [8]. Richetti, et al. manifested that AChE is an important biomarker for many environmental pollutants in zebrafish [9]. In ecotoxicology, cellular and biochemical parameters are strongly recommended to assess the effects of toxic chemicals to model organisms. Oxidative stress were quite important in the molecular mechanism related to OP-induced toxicity, and both superoxide dismutase (SOD) and catalase (CAT) are proper biomarkers of antioxidant [10], [11]. The SODs are a metalloenzyme group that catalyse the dismutation of the superoxide anion radical to hydrogen peroxide $\left(\mathrm{H}_{2} \mathrm{O}_{2}\right)$ plus water, thus protecting organism against oxidative damage. The primary role of CAT is to decompose $\mathrm{H}_{2} \mathrm{O}_{2}$, reducing the oxidation caused by $\mathrm{H}_{2} \mathrm{O}_{2}$ [12]. Antioxidant defense in cell plays a pivotal role in sustaining homeostasis of the organism, because it's the regime of antioxidant defense that removes reactive oxygen produced by the metabolism of extraneous chemicals in the body well under normal physiological conditions. Some of these enzymes involved in antioxidant defense can serve as good molecular bioindicators for contaminant-mediated oxidative stress as well as indicating the magnitude of the response in populations subjected to pollutants such as heavy metals and other toxins.

Fish, as the top predator of aquatic communities, are used broadly in the health assessment of aquatic ecosystems, because they had the largest magnitude of contaminant bioaccumulation in the food webs. Generally, for this reason, fish are used to assess the quality of aquatic systems and 
work as bio-indicators of environmental contamination. Exposure of fish to xenobiotics result in interaction between these chemicals and biological systems, and this may cause physiological and biochemical disturbances in fish. As fish are either directly exposed to these chemicals from agricultural fields by surface runoff of water or indirectly through the food chain of the ecosystem, thus contaminate of fish can then be used for biomonitoring on the existence and importance of these pollutants [11]. Zebrafish is used by biologists as one of the most important vertebrate models for basic physiological studies. Despite of its small size, many toxicological study can be carried out at the level of whole organ, tissue, or intact organism, because zebrafish can breed large quantities of offspring, easy to be cultured, and have some other merits as vertebrate model [7].

This study was aimed to investigate the acute toxicity of 2-chloro-4-(ethylamino)-6-(isopropylamino)- $S$-triazine (atrzine, ATR), O, O-dimethyl dithiophosphate of dietyl mercaptosuccinate (melathion, MAL) and cadmium $(\mathrm{Cd})$ on zebrafish. Primary physiological problems caused by the accumulation of these toxicants in zebrafish body were described, and the effects on AChE activity associated with antioxidant defense were studied. Beyond that, we also estimated the lipid and protein contents (energy reserves) in muscle and brain, indicating major physiological responses.

\section{MATERIALS AND METHODS}

Zebrafish samples used in this research were purchased from the Institute of hydrobiology, Chinese academy of Science, weighing 0.30 to $0.85 \mathrm{~g}$ and the body length ranged from 3.10 to $4.60 \mathrm{~cm}$. The fish samples were devided randomly to different experimental groups, kept in aquarium with $4 \mathrm{~L}$ dechlorinated tap water. The conditions were as follows: $\mathrm{pH} 7.6,25-28^{\circ} \mathrm{C}$, light:dark $12: 12$, and oxygen were blew continuously into the water during the study period. Test solution was renewed every two days. Zebrafish were kept for 96 hours, without feeding during the test period.

\section{A. Experimental Water and Stock Solution}

The standard analytic of ATR and MAL with a purity of 97\% and $95 \%$ respectively was purchased from Xingyinhe chemical engineering co.ltd. Standard solution $\left(1000 \mathrm{mg} \cdot \mathrm{L}^{-1}\right)$ of ATR and MAL was separately prepared by dissolving into $80 \%$ aceton. $\mathrm{CdCl}_{2} \cdot 2.5 \mathrm{H}_{2} \mathrm{O}$ was prepared in deionized water.

\section{B. Acute Toxicity Testing}

All experiments were conducted in a period of $96 \mathrm{~h}$, and each group was tested in triplicates. Each aquarium contained $4 \mathrm{~L}$ of exposure solution and ten fish. The exposure solution was aerated uninterruptedly and fully renewed every $48 \mathrm{~h}$, and the $\mathrm{pH}$ and temperature of the solution were measured every day. Fish were divided into two groups: control group, with acetone only for organophosphate pesticides; and experimental group, treated with a series of different concentrations of organophosphate insecticide \& herbicide $\left(0,2.5,5,10 \& 20 \mathrm{mg} \cdot \mathrm{L}^{-1}\right)$ and $\mathrm{Cd}(0,1,5,10,20 \&$ $\left.30 \mathrm{mg} \cdot \mathrm{L}^{-1}\right)$. During the experiment, behavioural changes of the fish were daily recorded, dead bodies were counted every $24 \mathrm{~h}$ and removed as soon as possible. The mortality rate was calculated at $96 \mathrm{~h}$ by Finney's Probit Analysis LC $_{50}$ determination method [13]. In the end, the living fish were killed in ice water. Tissues or organs such as head and muscle, were isolated on ice into $2 \mathrm{ml}$ eppendorf tubes for the following biomarker analysis (10 fish in each group).

\section{Bioconcentration Test}

The exposure solution was filtered through $0.22 \mu \mathrm{m}$ membrane and stored at $4{ }^{\circ} \mathrm{C}$ until it was analysed by high-performance liquid chromatography (HPLC) to determine the pesticide concentration in the solution. Pesticides were extracted from fish tissues through the method of [14]. Zebrafish body without its fins was crushed and pesticides were extracted from $2 \mathrm{~g}$ of sample, filtered onto $0.22 \mu \mathrm{m}$ membrane and analysed by HPLC. This system contained the SSI 2300-525HPLC: Detector: Variable dual wavelength $525 \mathrm{UV}$ detector; column: Apollo C18 column ( $250 \mathrm{~mm} \times 4.6 \mathrm{~mm}, 5 \mu \mathrm{m})$ ALLTECH company; the Series III pump Cschrom Plus chromatography workstation; column temperature: $30^{\circ} \mathrm{C}$. Pesticide detections were made in the UV region ( $\lambda=210 \mathrm{~nm}$ for $\mathrm{MAl}$ and $\lambda=254 \mathrm{~nm}$ for ATR). The mobile phase for malathion consisted of acetonitrile (70\%) and water $(30 \%), \mathrm{pH} 3.5$ and for atrazine it was acetonitrile (35\%) plus $0.025 \mathrm{M}$ dipotassium hydrogen phosphate $(\mathrm{pH}$ 3.0 with acetic acid) (65\%). The flow rate for the pesticides was $1.0 \mathrm{~mL} / \mathrm{min}$, and the injection volume was $20 \mu \mathrm{L}$. The retention time of malathion and atrazine were 5.2 and 11.08 min respectively. Under the chromatographic conditions, contents of pesticides was quantified using external standard described above, while $1 \mathrm{~g}$ of fish tissue was digested by $3 \mathrm{ml}$ $65 \% \mathrm{HNO}_{3}$ in pressurized borosilicate glass tubes at $100^{\circ} \mathrm{C}$ for $3 \mathrm{~h}$. The digestive was diluted to $20 \mathrm{ml}$ with deionized water before $\mathrm{Cd}$ concentration was estimated by the modified method of [2]. $10 \mathrm{ml}$ of filtered water sample and $200 \mu \mathrm{l}$ of concentrated $65 \% \mathrm{HNO}_{3}$ was added. Cd contents in water and tissue samples were detected by Inductively Coupled Plasma Mass Spectrometer (ICP-MS) in Faculty of Material \& Chemistry, China University of Geosciences, Wu Han.

\section{Biochemical Analysis}

After exposure, the muscle and brain tissues of zebrafish were homogenized into cold physiological saline solution $(0.86 \%$ of $\mathrm{NaCl})$ by the ratio of $1 / 10(\mathrm{w} / \mathrm{v})$ using a mortar and pestle, then centrifuged $10 \mathrm{~min}$ at $8000 \mathrm{r} / \mathrm{min}, 4^{\circ} \mathrm{C}$. The supernatant was used for biochemical analysis.

AchE activity was measured at $412 \mathrm{~nm}$ wavelength by the method of [15], with acetylcholine iodide and dithiobis nitrobenzoic acid as substrate. SOD activity was estimated by Bewley' NBT photochemical reduction reaction method modified by Beachchamp, and the absorbance was calculated at $560 \mathrm{~nm}$ with a micro plate reader. For the quantification of CAT activity, $30 \%$ hydrogen peroxide was diluted by phosphate buffer (PH 7.4, $60 \mathrm{mmol} \cdot \mathrm{L}^{-1}$ ) to a final concentration of $65 \mathrm{mmol} / \mathrm{mL}$ as substrate solution together with ammonium molybdate solution $\left(32.4 \mathrm{mmol} \cdot \mathrm{L}^{-1}\right)$, and the absorbance was measured at $450 \mathrm{~nm}$. The unit of enzyme activity was set as activity per milligram of protein. Total protein content was estimated at $595 \mathrm{~nm}$ by the technical method of [16], with bovine serum albumin as standard. The standard calibration curve was $\mathrm{y}=0.0051 \mathrm{x}-0.0013$, 
$\mathrm{R}^{2}=0.9993$. Lipid was extracted from $1 \mathrm{~g}$ of dried zebrafish body by the Soxhlet for $6 \mathrm{~h}$ and the percentage of total lipid content was calculated as: (weight of dry lipid/weight of sample)*100

\section{E. Statistical Analysis}

The median lethal concentration $\left(\mathrm{LC}_{50}\right)$ values and $95 \%$ confidence limits of ecotoxicology to zebrafish in $96 \mathrm{~h}$ were measured by Finney's Probit Analysis [13]. The bioconcentration factor (BCF) of the studied toxicants in zebrafish was calculated through the following formula: $\mathrm{BCF}=\mathrm{Cf} / \mathrm{Cw}$, where $\mathrm{Cf}$ represents the concentration of MAL, ATR and $\mathrm{Cd}$ in fish and $\mathrm{Cw}$ stands for the toxicant concentration in the exposure solution. One-way analysis of variance (ANOVA) was conducted to determine statistical significance among or between groups of different treatments. The confidence limit was set at 0.05 .

\section{RESULTS}

\section{A. The Poisoning Symptoms in Fish and Median Lethal} Concentration of Toxicity

Fish exposed to different concentrations of MAL, ATR and $\mathrm{Cd}$. The behavioral responses of zebrafish were observed daily during the $0-96 \mathrm{~h}$ acute toxicity tests. During exposure, fish were significantly influenced. They became motionless, stayed in one position without moving and sometimes swam or jumped away quickly to avoid the toxic water. The opercula were faster activity observed as floating on the surface and gulping air. Fish swam abnormally in aquaria with higher concentrations of toxicants. Fish's pigmentation also changed on its body. Eventually, they lost balance and awareness, and remained in an vertical position for a few minutes with the anterior side the mouth near the surface of the water, in an attempt to gulp air and tail in the downward direction. Soon they settled in the bottom of the aquarium, and after some time turned down and then died while the opercula remained wide open exposing the gills. $\mathrm{LC}_{50}$ is extensively used basis in acute toxicity test and so is the concentration of the chemical tested, which kills half of the tested organisms in a certain period of exposure, usually $96 \mathrm{~h}$. Generally in toxicity test, death is the decisive criterion, because it is easy to identify and clarify the biological and ecological importance. The $\mathrm{LC}_{50}$ values (with $95 \%$ confidence limits) of MAL, ATR and Cd were 5.29 (4.82-5.81), 9.57 (8.37-10.94) and 9.54 (8.26-11.03) $\mathrm{mg} \cdot \mathrm{L}^{-1}$ respectively (Table I). The tested fish mortality raised with increasing concentration of toxins and length of exposure, and this means that the toxicity is dose- and time-dependent. In this research we compared the effects of OP (MAL and ATR) and heavy metal (Cd) during the $96 \mathrm{~h}$ to zebrafish. Table I showed the sensitivity of fish, in terms of $96 \mathrm{~h} \mathrm{LC}_{50}$ followed the order: MAL $>\mathrm{Cd}>$ ATR.

\section{B. Bioconcentration of Toxicants and Total Lipid in Zebrafish Body}

The concentrations of MAL, ATR and Cd in fish body were detected during 96h (Fig. 1). The results indicated that for both treatments, the BFC rose with increasing toxicant concentrations. Total lipid content increased significantly at low concentration of toxicants compared with control group $(p<0.01)$, yet decreased slightly with the increase of toxin concentrations (Fig. 2).

TABLE I: LC 50 VALUES (WITH 95\% CONFIDENCE LIMIT) OF MAL, TR AND CD IN $\left(\mathrm{MG} \cdot \mathrm{L}^{-1}\right)$ OF ZEBRAFISH ESTIMATED BY FINNEY'S METHOD [13]

\begin{tabular}{cccc}
\hline \hline \multirow{2}{*}{ Chemical } & $\begin{array}{c}\mathrm{LC}_{50} \\
\text { value }\end{array}$ & 95\% confidence limit & $\mathrm{R}^{2}$ \\
\hline MAL & 5.29 & $4.82-5.81$ & 0.964 \\
ATR & 9.57 & $8.37-10.94$ & 0.922 \\
Cd & 9.54 & $8.26-11.03$ & 0.963 \\
\hline \hline
\end{tabular}

\section{Effects of Toxins on AchE Activities of Zebrafish Tissues}

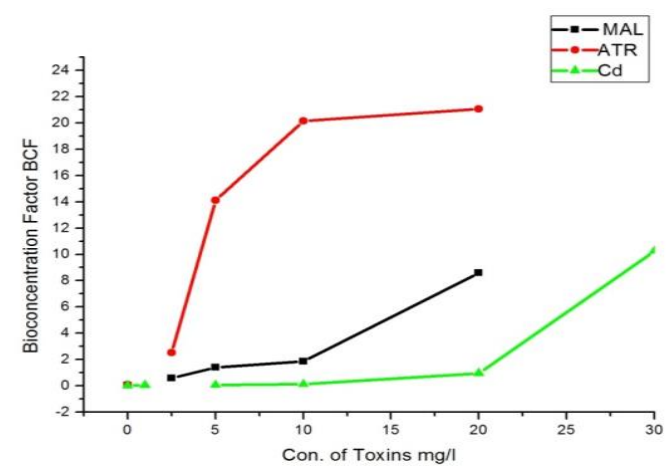

Fig. 1. Bioconcentration factor of MAL, ATR \& Cd of different concentrations in zebrafish at $96 \mathrm{~h}$

Compared with control group, the AchE activity in muscle decreased significantly $(p<0.01)$ by $49.37 \%, 54.40 \%$ and $77.01 \%$ respectively at $20 \mathrm{mg} \cdot \mathrm{L}^{-1}$ after $96 \mathrm{~h}$ (Table II). In brain, the activity of AchE increased $(p<0.05)$ along with the concentration gradient, the maximal increment occurred at 5 $\mathrm{mg} \cdot \mathrm{L}^{-1}$ of MAL, by $29.11 \%$, whereas significant increases of AchE activity were observed at highest concentrations of ATR \& Cd, by 9.65 and $38.49 \%$ respectively (Table II).

\section{Effect of Toxins on Antioxidant Enzyme Activity in Zebrafish Tissues}

The result showed that CAT activity increased significantly $(p<0.01)$ in muscle after exposure to different concentrations of acute toxicants for $96 \mathrm{~h}$. The increment of CAT activity reached highest at the concentration of 20 $\mathrm{mg} \cdot \mathrm{L}^{-1}$, namely $502.74 \%, 433.35 \%$ and $162.51 \%$ for MAL, ATR and Cd respectively, compared with control. SOD activity in muscle also increased significantly $(p<0.05)$ at 20 $\mathrm{mg} \cdot \mathrm{L}^{-1}$ of MAL, ATR and Cd, by $185.45 \%, 109.46 \%$ and $111.21 \%$ respectively. Whereas in brain, the maximal increments of CAT activity were observed at $5 \mathrm{mg} \cdot \mathrm{L}^{-1}$ of MAI and ATR, by $108.65 \%$ and $130.10 \%$ respectively after $96 \mathrm{~h}$ compared to control group. The SOD activity in brain increased significantly $(p<0.01)$ for all toxins exposure with increase of concentration when compared to control group (Table II). The supreme increase at $20 \mathrm{mg} \cdot \mathrm{L}^{-1}$ of MAL, 20 $\mathrm{mg} \cdot \mathrm{l}^{-1}$ of ATR and $5 \mathrm{mg} \cdot \mathrm{L}^{-1}$ of Cd was $114.09 \%, 121.86 \%$ and $353.26 \%$ respectively.

\section{E. Effects of Toxins on Protein Contents in Zebrafish Tissues}

The protein content in muscle was depressed significantly $(p<0.01)$ with increased toxin concentrations. When exposed 
to $20 \mathrm{mg} \cdot \mathrm{L}^{-1} \mathrm{MAL}$ after $96 \mathrm{~h}$, protein content decreased by $81.63 \%$, and under the same treatment of ATR $\left(20 \mathrm{mg} \cdot \mathrm{L}^{-1}\right.$, 96h) protein content declined by $64.85 \%$ (Table II). Differently, when composed to $\mathrm{Cd}$, the protein content showed a sharp decrement at $5 \mathrm{mg} \cdot \mathrm{L}^{-1}$, about $67.11 \%$. Significant decrease of protein content also occurred in zebrafish brain $(p<0.01)$, but different from that in muscle, maximum decrease appeared at $20 \mathrm{mg} \cdot \mathrm{L}^{-1}$ of ATR and $\mathrm{Cd}$, $66.32 \%$ and $53.43 \%$ respectively.
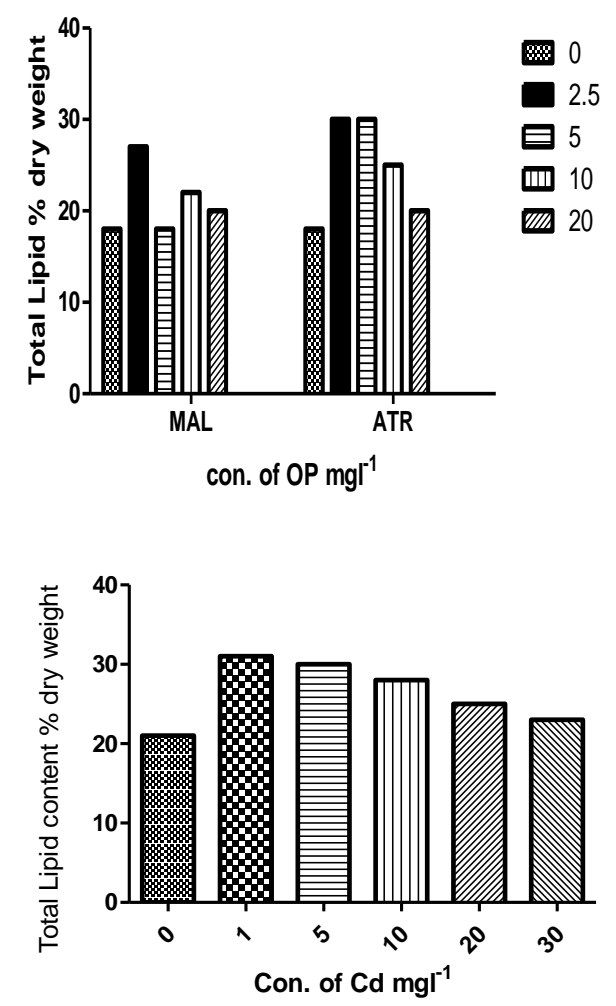

Fig. 2. Total lipid contents in zebrafish exposed to different acute concentrations of toxicants (MAL, ATR \& Cd).

\section{DISCUSSION}

Morphological and behavioral changes in fish are a good biomarker of the health status of freshwater bodies with respect to pollutants [17]. As well as the behavioral changes resulting from stress are considered more sensitive to signal potential toxic effects. Different behavioral changes mostly were noticed as less activity, lost of equilibrium, restlessness, abnormal swimming behavior, rapid gill movement, staying motionless on the aquarium bottom and change in the color of zebrafish skin which are similar to the observations of behavioural responses reported in previous studies [17]-[19]. It was reported that these behavioral abnormalities of fish (Labeo rohita) were observed only at high concentrations (values higher than $96 \mathrm{~h} \mathrm{LC}_{50}$ ) and after exposure to various acute concentrations $\left(5,10,15,20,25\right.$ and $\left.30 \mathrm{mg} \cdot \mathrm{L}^{-1}\right)$ of MAL [20].

A negative correlation exists between $\mathrm{LC}_{50}$ and the acute toxicity of chemicals. So $\mathrm{LC}_{50}$ is broadly used as a proper indicator for the acute toxicity of various chemicals in aquatic organisms. The sensitivity the fish to a particular toxic substance depends on many factors, such as species, age, feeding conditions, intermediary metabolism rate, weight, temperature, salinity, dissolved oxygen of the water, etc. [21]-[23]. The $\mathrm{LC}_{50}$ in this study at $96 \mathrm{~h}$ were 5.29, 9.57 and $9.54 \mathrm{mg} \cdot \mathrm{L}^{-1}$ for malathion, atrazine and Cadmium respectively. The results indicated that fish were more sensitive to malathion than the other two toxicants (atrazine and $\mathrm{Cd}$ ). According to the U. S. EPA, the toxicity of compounds to fish was classified as practically nontoxic $\left(\mathrm{LC}_{50}>100 \mathrm{mg} \cdot \mathrm{L}^{-1}\right)$, slightly toxic $\left(>10 \mathrm{mg} \cdot \mathrm{L}^{-1}\right.$ to 100 $\left.\mathrm{mg} \cdot \mathrm{L}^{-1}\right)$, moderately toxic $\left(>1 \mathrm{mg} \cdot \mathrm{L}^{-1}\right.$ to $\left.10 \mathrm{mg} \cdot \mathrm{L}^{-1}\right)$, highly toxic $\left(>0.1 \mathrm{mg} \cdot \mathrm{L}^{-1}\right.$ to $\left.1 \mathrm{mg} \cdot \mathrm{L}^{-1}\right)$, and very highly toxic $(<0.1$ $\left.\mathrm{mg} \cdot \mathrm{L}^{-1}\right)$ [24]. Besides, the $\mathrm{LC}_{50}$ values for malathion vary greatly and extending from toxic medium to very highly toxic, because the values of $\mathrm{LC}_{50}$ can be influenced by various factors such as age, size, and some inherent distinctions between different populations of the same species [24], [25]. Our results were similar to those of [26] who assessed the 96h $\mathrm{LC}_{50}$ value of commercial-grade malathion $(50 \% \mathrm{EC})$ of freshwater teleost fish (Channa punctatus) at $5.93 \mathrm{ppm}$ in a semi static system. Vittozi and De Angelis summed the $96 \mathrm{~h}$ $\mathrm{LC}_{50}$ value of malathion toxicity to different spices of fish, ranging from 0.09 to $22.09 \mathrm{ppm}$ [27]. According to U.S. EPA classification, toxins in this study were highly toxic. Yet the $96 \mathrm{~h} \mathrm{LC}_{50}$ of $9.57 \mathrm{mg} \cdot \mathrm{L}^{-1}$ reported for zebrafish exposed to atrazine in the present study was lower than the $96 \mathrm{~h} \mathrm{LC}_{50}$ values of $42.38 \mathrm{mg} \cdot \mathrm{L}^{-1}$ and $10.2 \mathrm{mg} \cdot \mathrm{L}^{-1}$ estimated by [18] for fish (Channa punctatus) and [28] for silver catfish (Rhamdia quelen) respectively. The distinction in toxicity of various types mentioned above is due to the differences in the absorption of pesticides, bioaccumulation, and excretion. Differences in metabolic pathways between species lead to different patterns of biotransformation consequently resulting in more or less toxic metabolites. The size of the toxic effects of pesticides also depends on the length and weight and respiratory rate [29] except time and concentrations. The $96 \mathrm{~h} \mathrm{LC} 50$ of $9.54 \mathrm{mg} \cdot \mathrm{L}^{-1}$ reported for zebrafish exposed to $\mathrm{Cd}$ in the present study was higher than $\mathrm{LC}_{50}$ value of cadmium chloride for the fish C. catla, namely, $4.53 \mathrm{mg} \cdot \mathrm{L}^{-1}$ recorded by [23]. Pantung reported the $\mathrm{LC}_{50}$ of $\mathrm{Cd}$ for catfish (Clarias macrocephalus $\mathrm{x}$ Clarias gariepinos) was $13.6 \mathrm{mg} \cdot \mathrm{L}^{-1}$, higher than the value in this study [30]. The $\mathrm{LC}_{50}$ of Cd for for tilapia O. niloticus and L. rohita were even higher, $24.66 \mathrm{mg} \cdot \mathrm{L}^{-1}$ and $22.92 \mathrm{mg} \cdot \mathrm{L}^{-1}$ respectively [31].

Pesticides and chemical pollutants seemed to be the primary cause of fish resource loss and posed detrimental impact on the ecosystem, aquaculture and human health, which finally brought about the study of acute toxicity [14]. This study manifested that MAL, ATR and Cd could be quickly accumulated in zebrafish body soon after exposure, and the maximal BCFs of toxins in fish were 21.06, 8.60 and 10.26 respectively in $20 \mathrm{mg} \cdot \mathrm{L}^{-1}$ of MAL and ATR, and 30 $\mathrm{mg} \cdot \mathrm{L}^{-1}$ of $\mathrm{Cd}$ after $96 \mathrm{~h}$ exposure. The study of [14] revealed that pyrimorph fungicide could be quickly accumulated in zebrafish exposed to a sublethal concentration of this toxicant, and the maximal BCFs of pyrimorph in zebrafish body were $1.07 \times 102(144 \mathrm{~h})$ and $23.1(96 \mathrm{~h})$ after exposure to 2.00 and $0.25 \mathrm{mg} \cdot \mathrm{L}^{-1}$ of pyrimorph respectively. Sun, et al. carried out a study, in which goldfish (Carassius auratus) were exposed to $1.0 \mathrm{mg} \cdot \mathrm{L}^{-1} \mathrm{HC}$ Orange No. 1 for $6,12,24$, $36,48,60,72$, and $96 \mathrm{~h}$, and stated that the toxcity started to accumulate in goldfish tissue right after exposure and peaked at a $24 \mathrm{~h}$ exposure [32]. 
TABLE II: CHANGES OF BIOCHEMICAL PARAMETERS IN MUSClE AND BRAIN OF ZEBRAFISH EXPOSED TO MAL, ATR \& CD FOR 96 H

\begin{tabular}{|c|c|c|c|c|c|c|c|c|c|}
\hline \multirow{2}{*}{\multicolumn{2}{|c|}{ Chemical $\left(\mathrm{mg} \cdot \mathrm{l}^{-1}\right)$}} & \multicolumn{2}{|c|}{ AchE mmol/min/mg prot. } & \multicolumn{2}{|c|}{ CAT U/mg prot. } & \multicolumn{2}{|c|}{ SOD U/mg prot. } & \multicolumn{2}{|c|}{ protein $\mathrm{mg} / \mathrm{g}$} \\
\hline & & Muscle & Brain & Muscle & Brain & Muscle & Brain & Muscle & Brain \\
\hline \multirow[t]{5}{*}{ MAL } & 0 & $1.15 \pm 0.11$ & $0.24 \pm 0.02$ & $69.17 \pm 1.52$ & $320.50 \pm 3.54$ & $8.61 \pm 0.36$ & $18.90 \pm 0.10$ & $13.29 \pm 0.91$ & $8.43 \pm 0.66$ \\
\hline & 2.5 & $0.48 \pm 0.01$ & $0.51 \pm 0.22$ & $166.07 \pm 2.17$ & $250.26 \pm 1.94$ & $11.75 \pm 0.53$ & $10.09 \pm 0.64$ & $7.12 \pm 0.08$ & $12.73 \pm 1.93$ \\
\hline & 5 & $0.30 \pm 0.03$ & $0.07 \pm 0.04$ & $109.40 \pm 3.11$ & $348.24 \pm 2.28$ & $8.14 \pm 0.45$ & $13.52 \pm 0.37$ & $4.36 \pm 0.98$ & $10.58 \pm 0.13$ \\
\hline & 10 & $0.54 \pm 0.11$ & $0.14 \pm 0.05$ & $200.58 \pm 1.01$ & $300.10 \pm 2.05$ & $9.76 \pm 0.54$ & $15.72 \pm 0.51$ & $3.99 \pm 1.13$ & $9.14 \pm 0.81$ \\
\hline & 20 & $0.57 \pm 0.04$ & $0.35 \pm 0.06$ & $347.76 \pm 1.95$ & $173.54 \pm 2.50$ & $15.96 \pm 0.68$ & $21.57 \pm 0.40$ & $2.44 \pm 0.07$ & $9.33 \pm 0.09$ \\
\hline \multirow[t]{5}{*}{ ATR } & 0 & $1.15 \pm 0.11$ & $0.26 \pm 0.02$ & $69.15 \pm 1.52$ & $320.00 \pm 3.54$ & $8.51 \pm 0.35$ & $18.86 \pm 0.61$ & $6.82 \pm 0.94$ & $17.63 \pm 1.67$ \\
\hline & 2.5 & $1.01 \pm 0.65$ & $0.37 \pm 0.25$ & $283.44 \pm 2.43$ & $312.52 \pm 1.78$ & $7.01 \pm 0.703$ & $9.23 \pm 0.52$ & $4.00 \pm 0.74$ & $7.39 \pm 0.43$ \\
\hline & 5 & $0.72 \pm 0.03$ & $0.58 \pm 0.34$ & $102.47 \pm 1.75$ & $416.33 \pm 3.06$ & $2.09 \pm 0.64$ & $10.86 \pm 0.61$ & $4.26 \pm 1.43$ & $14.77 \pm 3.15$ \\
\hline & 10 & $0.36 \pm 0.04$ & $0.78 \pm 0.17$ & $268.20 \pm 3.29$ & $362.81 \pm 1.98$ & $8.05 \pm 0.67$ & $22.33 \pm 0.47$ & $4.28 \pm 0.85$ & $10.72 \pm 0.15$ \\
\hline & 20 & $0.63 \pm 0.01$ & $0.02 \pm 0.39$ & $299.67 \pm 2.36$ & $338.02 \pm 2.14$ & $9.31 \pm 0.57$ & $22.99 \pm 0.697$ & $2.40 \pm 0.44$ & $5.94 \pm 0.31$ \\
\hline \multirow[t]{6}{*}{$\mathrm{Cd}$} & 0 & $0.80 \pm 0.08$ & $0.74 \pm 0.35$ & $348.75 \pm 2.65$ & $336.29 \pm 1.62$ & $12.85 \pm 0.60$ & $6.19 \pm 0.57$ & $2.10 \pm 1.28$ & $3.09 \pm 0.42$ \\
\hline & 1 & $1.64 \pm 0.08$ & $0.33 \pm 0.014$ & $295.69 \pm 0.22$ & $144.70 \pm 0.92$ & $30.84 \pm 0.59$ & $15.67 \pm 1.18$ & $1.067 \pm 0.05$ & $1.90 \pm 0.74$ \\
\hline & 5 & $0.49 \pm 0.02$ & $0.52 \pm 0.04$ & $100.80 \pm 0.85$ & $215.21 \pm 1.56$ & $18.58 \pm 0.30$ & $21.86 \pm 0.96$ & $0.69 \pm 1.16$ & $1.76 \pm 0.28$ \\
\hline & 10 & $0.85 \pm 0.03$ & $0.52 \pm 0.01$ & $93.94 \pm 1.44$ & $148.73 \pm 2.64$ & $13.82 \pm 0.58$ & $18.69 \pm 0.47$ & $0.73 \pm 0.67$ & $1.59 \pm 0.58$ \\
\hline & 20 & $0.88 \pm 0.107$ & $0.29 \pm 0.04$ & $185.03 \pm 1.08$ & $115.15 \pm 2.23$ & $11.07 \pm 0.66$ & $16.33 \pm 0.63$ & $0.73 \pm 0.85$ & $1.44 \pm 0.55$ \\
\hline & 30 & $0.61 \pm 0.11$ & $0.28 \pm 0.03$ & $480.52 \pm 2.79$ & $86.19 \pm 1.54$ & $14.29 \pm 0.91$ & $15.99 \pm 1.41$ & $1.64 \pm 0.37$ & $2.02 \pm 0.51$ \\
\hline
\end{tabular}

The standard deviations values in the same row with different significantly at $(p<0.05)$

Enzymatic changes was considered to be important indication of hazardous chemicals. Many studies have shown that the activity of AchE was inhibited after OPs exposure, and thus it was used to monitor the neurotoxicity of OPs. Inhibition to the AchE activities was dose- and time-dependent, and the rate of inhibition was also related to species and age [33]. The inhibition of AchE activity is widely used as a good biomarker for exposure to toxic OP as well as cadmium contamination [34]. In our study, AchE activity in brain and muscle of zebrafish was significantly $(p<0.05)$ inhibited when treated with OP (MAL, ATR) and Cd. Hence, we suggested that AchE activity inhibition can be used as a biomarker to the toxicity of OP and heavy metal cadmium. In line with our results, Richetti, et al. had evaluated effect of four heavy metal compounds (zinc chloride, cadmium acetate, lead acetate, and mercury chloride) on the AchE activity in zebrafish brain and inhibition on $\mathrm{AChE}$ activity was observed only at high concentrations of $\mathrm{Hg}^{2+}$ whereas the lower doses of this metal did not alter the enzyme activity [9]. Senger, et al. suggested that pesticides can directly interact with cholinergic receptors at or even below the concentration at which AchE is inhibited [7]. Feng investigated AchE inhibition in muscle of $T$. niloticain caused by trichlorfon [35]. They found that inhibition degree of the enzyme had a positive relationship with the pesticide concentration and exposure time. And they pointed out that AChE inhibition is a well acceptable indicator of organophosphates toxicity and other xenobiotics both in vivo and vitro.

Changes of antioxidant activity under chemical pressure are subjected to the severity and duration of stress applied, as well as susceptibility of the exposed species. But this is not necessarily the general rule that an increase in the concentrations of xenobiotic induces antioxidant activity [36]. Oruc and Usta [33] also found that the antioxidant system in different tissues showed the different responding patterns to oxidative stress. In this study, an increasing trend of SOD and CAT activities were observed in the tissues of zebrafish exposed to MAL, ATR and $\mathrm{Cd}$, and a more pronounced increase was found in muscle with increased toxin concentration, especially at high concentration for all toxicants. It was supposed that the increase in SOD activity was primarily due to higher $\mathrm{O}_{2}$-production [37]. As the first defense mechanism against oxidative stress, antioxidant defense works to protect living organism from free radicals produced by oxidation and other stress, thus having great significance for fish [11]. In the present study, the increase in SOD activity in exposed zebrafish tissue was possibly related 
to increased oxidative stress caused by OP (MAL, ATR) and heavy metal $(\mathrm{Cd})$, and this was consistent with the study of [38], who inquired into the changes of SOD activity caused by chlorpyrifos exposure in adult Oreochromis niloticus. Nogueira, et al. [39] found higher SOD activity in gills of two species, Nile tilapia (Oreochromis niloticus) and armoured catfish (Pterygoplichthys anisitsi) exposed to diesel oil, and referred to the elevated SOD activity in their study may be to protect cells against oxidative damage. The rise of CAT activities in zebrafish brain and muscle observed in the present study may be a response to $\mathrm{H}_{2} \mathrm{O}_{2}$ production catalysed by activated SOD, because CAT is involved in the detoxification of $\mathrm{H}_{2} \mathrm{O}_{2}$ in water. This proved that SOD and CAT had a positive correlation in muscle and brain. Increased SOD activity promoted the $\mathrm{H}_{2} \mathrm{O}_{2}$ production, which needed higher CAT activity to be resolved. This explained why the toxicants used in this study caused significant increase $(P<0.05)$ in the activities of SOD and CAT in exposed zebrafish. This was in accordance with the research of [11], showing increased CAT and SOD levels in guppy fish (Poecilia reticulata) brain and gills exposed to chlorpyrifos for $96 \mathrm{~h}$. Eyckmans, et al. noted that increase of SOD and CAT activity in common carp are higher than that in gibel carp, as well as increased SOD activity in rainbow trout tissues after $96 \mathrm{~h}$ exposure to copper as they respond to metal stress [4]. Consequently, the CAT antioxidant is a very important component of intracellular antioxidant defense system in organisms, because it reduces $\mathrm{H}_{2} \mathrm{O}_{2}$ and oxygen to prevent oxidative stress [36], [40]. Radwan, et al. reported significant CAT activity increase in Theba pisana exposed to trace metals $(\mathrm{Cu}, \mathrm{Pb}$ and $\mathrm{Zn})$ after $48 \mathrm{~h}$, and they suggested this increase in antioxidant defenses may protect the cells from damage, maintaining cell homeostasis [3].

Changes of biochemical parameters like protein and lipid content are important indicators of the organ sensitivity to pollutants. Proteins are important organic materials and necessary to build tissue in the organism and also play an important role in the metabolism of energy [41]. As well, proteins are essential molecules in any living system, including enzymes, structural materials, lubricants and carrier particles [42]. This study showed a significant decrease $(p<0.05)$ in protein content in muscle after exposure to acute concentration of MAL, ATR and Cd, as well as in brain to some above toxicants compared to control groups. This is similar to investigations of [42] on depletion level of protein in different fishes under the stress of copper Sulphate. Many previous studies pointed out a gradual decline in protein content of fish exposed to toxicants and suggested that may be due to a metabolic disorder of carbohydrate and protein, destroying the protein synthesis machinery and inhibiting ATP synthesis. The depletion of protein can also be attributed to spontaneous use of amino acids in mixed catabolic reactions within organism in order to combat stress condition [20]. Susan [43] observed that the protein content declined in different tissues of Labeo rohita and Cirrhinus mrigala exposed to concentrations of sublethal and lethal of pyrethroid, and noted that it was likely due to the use of the metabolism of ketoacids for gluconeogenesis path for the synthesis of glucose, or because of direct free amino acids for the manufacture of proteins necessary. The study of [44] showed significant decline in protein content in Tilapia Fish (Oreochromis Niloticus) liver after exposed to insecticide, probably due to increased metabolism and proteolysis under the stress of toxicants, as well as impaired protein synthesis resulting from liver disorders.

Biological studies have verified that as source of energy for metabolism in fish, lipid is very important during stress periods, when overall energy consumption increases, and expensive processes need to be restrained. And accordingly, it invokes compensatory metabolic changes are promoted in the tissues to regulate the quantity and quality of many metabolites, including lipids [45]. This work proved that total lipids content increased in the studied zebrafish tissues exposed to OP (MAL, ATR) and Cd compared to control groups. Fig. 2 shows lipogenesis. It is a clear indication of the metabolic transformation of carbohydrates into lipids by acetyl-CoA barriers. Degradation of amino acids gives rise to keto acids, and provides the acetate units to be lipogenesis. The acetyl-CoA may be condensed with fatty acids found, which may continue to increase the length of fatty acids chain [46]. It Can be considered that this strategic move for the animal to isolate the pesticide and maintain dynamic reorganization of metabolism to maintain the integrity of the cellular tissue of stress in acute toxicity. Lipid content of organisms can be affected by different factors like age, sex, and food supplies. It was noticed that lipid content increase in animals was probably due to the exposure to stressful conditions, and the biotransformation of other organic components to lipids. [47] found lipid contents increased in both selected models, Lamellidens corrianus and Parreysia cylindrica after acute and chronic exposure of chloramphenicol. Meanwhile, the increased lipid content in fish could protect them from the toxic effects of lipophilic chemicals as a reservoir protection of aquatic organisms, and they are converted from target organs potential to fatty tissue. However, it can inevitably cause damage, for organisms rich in lipid content give rise to bio-concentration of toxicants and pose detrimental effect to food chains in which human are involved.

\section{CONCLUSION}

This work showed that zebrafish was quite sensitive to the studied toxicants following the order: MAL $>\mathrm{Cd}>$ ATR and their mortality rate depend on the concentration of toxins. The tolerance of zebrafish to dose-dependent bioaccumulation of toxicants is a strong indicator of whether it's a suitable model in biomonitoring programs. Additionally, several properties of zebrafish also enable them to provide a measure of aquatic pollution with visible cellular and physiological responses, and work as sentinels for water quality monitoring. Biological trials with various endpoints can provide sensitive approaches to predicting the potential risk of OP and $\mathrm{Cd}$, which are useful in formulating the "safe levels" of these bioaccumulative toxicants. Therefore, there is a need for studies on the sensitivity of genotoxic effects of pesticides and heavy metals on aquatic organisms, especially fish in assessing the potential risk of similar species in the natural environment.

The present work is a biomonitoring study in which the 
enzymatic stress indices and biochemical response were used to evaluate the effects of OP pesticides and heavy metal to aquatic organisms, zebrafish. Yet this study did not take all factors of the circumstances into consideration. Therefore, future studies may explore whether induction of these parameters are suitable for water mornitoring as early biomarkers for toxicants.

\section{REFERENCES}

[1] C. A. O. Ribeiro, Y. Vollaire, A. Sanchez-Chardi, and H. Roche, "Bioaccumulation and the effects of organochlorine pesticides, PAH and heavy metals in the Eel (Anguilla anguilla) at the Camargue Nature Reserve, France," Aquat Toxicol., 2005, vol. 74, pp. 53-69.

[2] S. Cambier, P. Gonzalez, G. Durrieu, and J. P. Bourdineaud, "Cadmium-induced genotoxicity in zebrafish at environmentally relevant doses," Ecotox Environ Safe, 2010, vol. 73, pp. 312-319.

[3] M. A. Radwan, K. S. El-Gendy, and A. F. Gad, "Oxidative stress biomarkers in the digestive gland of Theba pisana exposed to heavy metals," Arch Environ Con Tox., 2010, vol. 58, no. 3, 828-835.

[4] M. Eyckmans, N. Celis, N. Horemans, R. Blust, and G. D. Boeck, "Exposure to waterborne copper reveals differences in oxidative stress response in three freshwater fish species," Aquat Toxicol., 2011, vol. 103, pp. 112-120.

[5] K. Kumar and B. Ansari, "Malathion toxicity: Effect on the liver of the fish Brachydanio rerio (Cyprinidae)," Ecotox Environ Safe, 1986, vol. 12, pp. 199-205.

[6] M. N. Wacksman, J. D. Maul, and M. J. Lydy, "Impact of atrazine on chlorpyrifos toxicity in four aquatic vertebrates," Arch Environ Contam Toxicol., 2006, vol. 51, pp. 681-689.

[7] M. R. Senger, E. P. Rico, M. B. Arizi, D. B. Rosemberg, R. D. Dias, M. R. Bogoa, and C. D. Bonana, "Carbofuran and malathion inhibit nucleotide hydrolysis in zebrafish (Danio rerio) brain membranes," Toxicology, 2005, vol. 212, pp. 107-115.

[8] M. Solé, M. Baena, S. Arnau, M. Carrasson, F. Maynou, and J. E. Cartes, "Muscular cholinesterase activities and lipid peroxidation levels as biomarkers in several Mediterranean marine fish species and their relationship with ecological variables," Environ Int., 2010, vol. 36 , pp. 202-211.

[9] S. K. Richetti, D. B. Rosemberg, J. Ventura-Lima, J. M. Monserrat, M. R. Bogo, and C. D. Bonan, "Acetylcholinesterase activity and antioxidant capacity of zebrafish brain is altered by heavy metal exposure," Neurotoxicology, 2011, vol. 32, pp. 116-122.

[10] C. C. C. Cheung, G. J. Zheng, P. K. S. Lam, and B. J. Richardson, "Relationships between tissue concentrations of chlorinated hydrocarbons (polychlorinated biphenyls and chlorinated pesticides) and antioxidative responses of marine mussels, Perna viridis," Mar Pollut Bull, 2002, vol. 45, pp. 181-191.

[11] A. A. Sharbidre, V. Metkari, and P. Patode, "Effect of methyl parathion and chlorpyrifos on certain biomarkers in various tissues of guppy fish, Poecilia reticulata," Pestic Biochem Phys., 2011, vol. 101, pp. 132-141.

[12] B. J. Richardson, E. Mak, S. B. D. Luca-Abbott, M. Martin, K. McClellan, and P. K. S. Lam, "Antioxidant responses to polycyclic aromatic hydrocarbons and organochlorine pesticides in green-lipped mussels (Perna viridis): Do mussels "integrate" biomarker responses?" Mar Pollut Bull, 2008, vol. 57, pp. 503-514.

[13] D. J. Finney, Probit Analysis, 3d Ed, Cambridge: Cambridge University Press, 1971

[14] C. Zhao, B. Liu, J. Wang, N. Li, Z. Qin, and L. Qiu, "Acute toxicity and bioconcentration of pyrimorph in zebrafish, Brachydanio rerio," Pest Manag Sci, vol. 67, pp. 1178-1183, 2011.

[15] G. L. Ellman, K. D. Courtney, V. Andres, and R. M. Featherstone, "A new and rapid colorimetric determination of acetylcholinesterase activity," Biochemical pharmacology, vol. 7, pp. 91-95, 1961.

[16] M. M. Bradford, "A rapid and sensitive method for the quantitation of microgram quantities of protein utilizing the principle of protein-dye binding," Analytical biochemistry, vol. 72, pp. 248-254, 1976.

[17] B. T. Kaushal, and A. A. Mishra, "comparative toxicity analysis of cadmium compounds on morphological and behavioral aspects in air breathing freshwater fish Channa punctatus," International Journal of Science and Nature, vol. 2, pp. 266-269, 2011.

[18] C. D. Nwani, N. S. Nagpure, R. Kumar, B. Kushwaha, P. Kumar, and W. S. Lakra, "Lethal concentration and toxicity stress of Carbosulfan, Glyphosate and Atrazine to freshwater air breathing fish Channa punctatus (Bloch)," International Aquatic Research, vol. 2, pp. 105-111, 2010.

[19] E. O. Lawson, P. E. Ndimele, A. A. Jimoh, and O. O. Whenu, "Acute Toxicity of Lindane (Gamma Hexachloro-Cyclohexane) to African Catfish (Clarias gariepinus, Burchell, 1822)," International J ournal of Animal and Veterinary Advances, vol. 3, pp. 63-68, 2011.

[20] C. Thenmozhi, V. Vignesh, R. Thirumurugan, and S. Arun, "Impacts of Malathion on mortality and biochemical changes of freshwater fish Labeo Rohita," Iranian Journal of Environmental Health Science \& Engineering, vol. 8, pp. 325-332, 2011.

[21] M. Hrovat, H. Segner, and S. Jeram, "Variability of in vivo fish acute toxicity data," Regulatory Toxicology and Pharmacology, vol. 54, pp. 294-300, 2009.

[22] S. Yaqub and M. Javed, "Acute toxicity of water-borne and dietary cadmium and cobalt for fish," International Journal of Agriculture \& Biology, vol. 14, pp. 276-280, 2012.

[23] K. Sobha, A. Poornima, P. Harini, and K. Veeraiah, "A study on biochemical changes in the fresh water fish, Catla catla (hamilton) exposed to the heavy metal toxicant cadmium chloride," Kathmandu University Journal of Science, Engineering and Technology, vol. 3, pp. 1-11, 2007.

[24] R. D. Patrick, Malathion, Human Health and Ecological Risk Assessment, 2008.

[25] P. R. Durkin, Malathion, Human Health and Ecological Risk Assessment, Syracuse Environmental Research Associates, Inc. Fayetteville, New York, 2008.

[26] R. Kumar, N. S. Nagpure, B. Kushwaha, S. K. Strivastava, and W. S. Lakra, "Investigation of the genotoxicity of malathion to freshwater teleost fish Channa punctatus (Bloch) using the micronucleus test and comet assay," Archives of Environmental Contamination and Toxicology, vol. 58, pp. 123-130, 2010.

[27] L. Vittozzi and G. Angelis, "A critical review of comparative acute toxicity data on freshwater fish," Aquatic Toxicology, vol. 19, pp. 167-204, 1991.

[28] L. C. Kreutz, L. J. G. Barcellos, T. O. Silva, D. Anziliero, D. Martins, M. Lorenson, A. Marteninghe, and L. B. Silva, "Acute toxicity test of agricultural pesticides on silver catfish (Rhamdia quelen) fingerlings," Ciencia Rural, Santa Maria, vol. 38, pp. 1050-1055, 2008.

[29] K. A. Al-Ghanim, "Acute toxicity and effects of sub-lethal malathion exposure on biochemical and haematological parameters of Oreochromis niloticus," Scientific Research and Essays, vol. 7, pp. 1674-1680, 2012.

[30] N. Pantung, K. G. Helander, H. F. Helander, and V. Cheevaporn, "Histopathological alterations of hybrid Walking catfish (Clarias macrocephalus x Clarias gariepinus) in acute and subacute cadmium exposure," Environment Asia, vol.1, pp. 22-27, 2008.

[31] A. Latif, M. Ali, R. Kaoser, R. Iqbal, K. Umer, M. Latif, S. Qadir, and F. Iqbal, "Effect of cadmium chloride and ascorbic acid exposure on the vital organs of freshwater Cyprinid, Labeo rohita," African Journal of Biotechnology, vol. 11, pp. 8398-8430, 2012.

[32] Y. Sun, H. Yu, J. Zhang, Y. Yin, H. Shen, H. Liu, and X. Wang, "Bioaccumulation and antioxidant responses in goldfish Carassius Auratus under HC orange No. 1 exposure," Ecotoxicology and Environtal Safety, vol. 63, pp, 430-437, 2006.

[33] E. O. Oruc and D. Usta, "Evaluation of oxidative stress responses and neurotoxicity potential of diazinon in different tissues of Cyprinus carpio," Environmental Toxicology and Pharmacology, vol. 23, pp. 48-55, 2007.

[34] E. W. M. Roex, R. Keijzers, A. M. Cornelis, and V. Gestel, "Acetylcholinesterase inhibition and increased food consumption rate in the zebrafish, Danio rerio, after chronic exposure to parathion," Aquatic Toxicology, vol. 64, pp. 451-460, 2003.

[35] T. Feng, Z. B. Li, X. Q. Guo, and J. P. Guo, "Effects of trichlorfon and sodium dodecyl sulphate on antioxidant defense system and acetylcholinesterase of Tilapia nilotica in vitro," Pesticide Biochemistry and Physiology, vol. 92, pp. 107-113, 2008.

[36] M. L. Ballesteros, D. A. Wunderlin, and M. A. Bistoni, "Oxidative stress responses in different organs of Jenynsia multidentata exposed to endosulfan," Ecotoxicology and Environmental Safety, vol. 72, pp.199-205, 2009.

[37] K. H. Lüchmann, J. J. Mattos, M. N. Siebert, N. Siebert, N. Granucci et al., "Biochemical biomarkers and hydrocarbons concentrations in the mangrove oyster Crassostrea brasiliana following exposure to diesel fuel water-accommodated fraction," Aquatic Toxicology, vol.105, pp. 652-660, 2011.

[38] E. O. Oruc, "Oxidative stress, steroid hormone concentrations and acetylcholinesterase activity in Oreochromis niloticus exposed to 
chlorpyrifos," Pesticide Biochemistry Physiology, vol. 96, pp. 160-166, 2010.

[39] L. Nogueira, A. C. F. Rodrigues, C. P. Tridico, E. F. Fossa, and E. A. Almeida, "Oxidative stress in Nile tilapia (Oreochromis niloticus) and armored catfish (Pterygoplichthys anisitsi) exposed to diesel oil," Environmental monitoring and assessment, vol. 180, pp. 243-255, 2011.

[40] N. Kamel, H. Attig, A. Dagnino, H. Boussetta, and M. Banni, "Increased temperatures affect oxidative stress markers and detoxification response to benzo[a]pyrene exposure in mussel Mytilus galloprovincialis," Archives of Environmental Contamination and Toxicology, vol. 63, pp. 1-10, 2012.

[41] P. H. Yiu, J. See, A. Rajan, and C. F. J. Bong, "Boric acid levels in fresh noodles and fish ball," American Journal of Agricultural and Biological Sciences, vol. 3, pp. 476-481, 2008.

[42] S. J. Kawade and Y. K. Khillare, "Toxicity of zinc on the biochemical contents of certain tissues of freshwater fish, channa gachua (HAM.)," International Journal of Applied Biology and Pharmaceutical Technology, vol. 3, pp. 242-251, 2012.

[43] T. A. Susan, K. Sobha, K. Veeraiah, and K. Tilak, "Studies on biochemical changes in the tissues of Labeo rohita and Cirrhinus mrigala exposed to fenvalerate technical grade," Journal of Toxicology and Environmental Health Sciences. vol. 2, pp. 53-62, 2010.

[44] M. A. Al-Kahtani, "Effect of an insecticide abamectin on some biochemical characteristics of Tilapia fish (Oreochromis niloticus)," 2011.

[45] S. J. Tulasi, P. U. M. Reddy, and J. V. Ramana Rao, "Accumulation of lead and effects on total lipids and lipid derivatives in the freshwater fish Anabas testudineus (Bloch)," Ecotoxicology and Environmental Safety, vol. 23, pp.33-38, 1992.

[46] H. P. Gurushankara, S. V. Krishnamurthy, and V. Vasudev, "Effect of malathion on survival, growth, and food consumption of Indian cricket frog (Limnonectus limnocharis) tadpoles," Archives of Environmental Contamination and Toxicology, vol. 52, pp. 251-256, 2007.

[47] H. P. Nandurkar and S. P. Zambare, "Comparative study of acute and chronic exposure of chloramphenicol on total lipid contents in different tissues of model animals, Lamellidens corrianus (Lea) and Parreysia cylindrica (Annandale and Prashad)," International Multidisciplinary Research Journal, vol. 2, pp. 33-35, 2012.

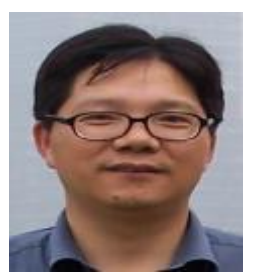

Yan Yunjun was born at Luotian county, Hubei province, China, in September 1969. He received B.S. in biology, Central China Normal University, Wuhan in 1993 and M.S. in zoology, Central China Normal University, Wuhan in 1995. He was also $\mathrm{Ph} . \mathrm{D}$. in hydrobiology, Institute of Hydrobiology, the Chinese Academy of Sciences, Wuhan, P. R. China, in 1998. In 2002 he is professor of biotechnology and from 2012 till Present is Vice Dean of College of Life Sciences and Technology, College of Life Sciences and Technology, Huazhong University of Science and Technology; 1037, Luoyu Road, Hongshan District, Wuhan, China.

Prof. Yan is senior committee member of the Chinese Society of Biological Engineering and Chinese Society of Microbiology. He holds a Second-grade Award from China Medical Association in 2009, and from Journal "Chinese Journal of Biotechnology" in 2009 and 2011.

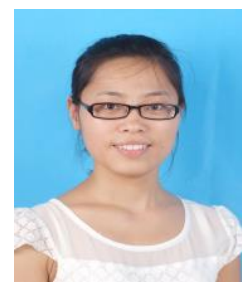

Wang Lixiao was born at Pingshan county, Hebei province, China, in June, 1990. She received B. S. in biotechnology, Huazhong University of Science and Technology, Wuhan, P. R. China in 2012. Now she is a Ph.D. student in College of Life Science and Technology, Huazhong University of Science and Technology, Wuhan, P. R. China.

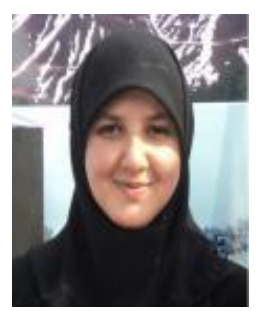

Abeer Ghazie A. Al-Sawafi was born at Basrah city, Iraq, on 6 June, 1978. She received B.S. in Biology Department, Science College, in 2000 and the M.S. in environmental pollution, Biology Department, Science College, Basrah University, Iraq, in 2005. Now, she is Ph.D. candidate in College of Life Science and Technology, Huazhong University of Science and Technology, Wuhan, China. She is (2001-2013) a lecturer in environmental and Pollution Engineering Department, Technical College, Foundation of Technical Education, Iraq. 